Z. Klin. Chem. Klin. Biochem.

13. Jg. 1975, S. 17-19

\title{
True Arrhenius Relationships of Human Lactate Dehydrogenase
}

\author{
By M. J. McQueen
}

From The Biochemistry Department, Royal Infirmary, Glasgow, Scotland

(Eingegangen am 10. Mai/12. August 1974)

The pyruvate and NADH concentrations and the buffer $\mathrm{pH}$ which gave maximal activity with LDH isoenzymes derived from human heart and liver tissue were established for the temperatures $25^{\circ} \mathrm{C}, 30^{\circ} \mathrm{C}, 35^{\circ} \mathrm{C}, 37^{\circ} \mathrm{C}, 40^{\circ} \mathrm{C}, 45^{\circ} \mathrm{C}$, and $50^{\circ} \mathrm{C}$. The velocities of the LDH isoenzymes using these maximal assay conditions were used to obtain Arrhenius plots, i.e. log initial velocity against inverse absolute temperature. The Arrhenius plots were linear with both isoenzyme preparations up to $45^{\circ} \mathrm{C}$. Between $45^{\circ} \mathrm{C}$ and $50^{\circ} \mathrm{C}$ it appeared that this linear relationship no longer held, particularly with the liver tissue. When the activation energies were calculated both isoenzyme preparations exhibited several points of inflexion, in each case occuring at the same temperatures. These inflexions represent a change in the reaction kinetics, possibly a conformational change in the enzyme. The results also indicate that the LDH 1 and2 isoenzymes are more efficient than LDH 4 and 5.

Um Lactatdehydrogenase-Isoenzyme aus Herz und Leber des Menschen bei maximaler Aktivität messen zu können, wurden die dafür erforderlichen Substratkonzentrationen (Pyruvat, NADH) und pH-Werte für die Temperaturen $25,30,37,40,45$. und $50^{\circ} \mathrm{C}$ ermittelt Die unter solchen Bedingungen gemessenen Geschwindigkeiten der Lactatdehydrogenase-Isoenzyme wurden nach Arrhenius aufgetragen (log Anfangsgeschwindigkeit gegen reziproke absolute Temperatur). Die Arrhenius-Plots waren für beide Isoenzyme bis $45^{\circ} \mathrm{C}$ linea:- Zwischen 45 und $50^{\circ} \mathrm{C}$ scheint diese lineare Beziehung besonders für Lebergewebe nicht mehr zu gelten. Bei der Bestimmung der Aktivierungsenergie wurden für beide Isoenzympräparate mehrere Knicke, jeweils bei derselben Temperatur, beobachtet. Diese Knicke sind durch eine Änderung der Reaktionskinetik, möglicherweise der Enzymkonformation, bedingt. Die Ergebnisse sprechen außerdem dafür, daß die Isoenzyme $\mathrm{LDH}_{1}$ und $\mathrm{LDH}_{2}$ wirksamer sind als $\mathrm{LDH}_{4}$ und $\mathrm{LDH}_{5}$.

It can hardly be disputed that most clinical chemists accept the need for international agreement on standardization of the conditions under which enzyme activities are measured. Efforts to obtain such agreement have been hindered by a failure to agree upon a standard temperature. Some of the arguments in the controversy relating to whether enzyme activity should be measured at $25^{\circ} \mathrm{C}, 30^{\circ} \mathrm{C}$ or $37^{\circ} \mathrm{C}$ have been based on incomplete experimental evidence. A less than expected increase in enzyme activity between $25^{\circ} \mathrm{C}$ and $37^{\circ} \mathrm{C}$ has been used to support the argument that the enzyme has been partially denatured (or inactivated) at the higher temperature (1). The experimental evidence to support this argument was obtained by calculating the deviation of the measured activity from the activity calculated from an Arrhenius plot (1). Such experimental work is based on the assumption that a substrate concentration which saturates the enzyme at one temperature will saturate it at another. Activation energies obtained from enzyme reaction velocities and the Arrhenius equation are meaningful only if the velocities are those obtained when the enzyme is saturated with substrate (2).

The study described in this paper aimed at obtaining true Arrhenius relationships of lactate dehydrogenase isoenzymes derived from human heart and liver tissue by measuring the enzyme activity at $25,30,35,37,40$, 45 , and $50^{\circ} \mathrm{C}$. To obtain these relationships it was necessary to measure enzyme activity using the pyruvate and NADH concentrations and the buffer $\mathrm{pH}$ which gave maximal activity with each tissue at each temperature.

\section{Materials and Methods}

Instruments

LKB 8600 Reaction Rate Analyser adjusted so that any of the temperatures stated earlier could be selected. The timing cam was also adjusted so that the timing mechanism would change at 30 second intervals.

LKB 8620 cooling stage.

Electronic instruments Ltd. 2320 pH meter.

\section{Enzymes}

Human heart and liver tissue was obtained at post-mortem examination. The tissues were washed to remove blood. Approximately $2 \mathrm{~g}$ of each tissue was minced and $100 \mathrm{ml}$ of $67 \mathrm{mmol} / 1$ S $\phi$ rensen phosphate buffer pH 7.2 at $0-5^{\circ} \mathrm{C}$ was added. The tissues were then homogenized and filtercd through eight layers of cotton gauze. The filtrate was then diluted with phosphate buffer containing $50 \mathrm{~g}$ of albumin per litre. 
Purified enzymcs were not used as one aim of the study was to judge the significance of any deviation from linearity of the Arrhenius plots. Instability of the purified enzyme molecule may produce such deviation as may molecular changes produces during the various purification steps. Tissue homogenates had the advantage of providing a physiological buffered state in which to measure the lactate dehydrogenase activity.

\section{Procedure}

Sodium pyruvate was prepared in a broad range of reaction concentrations from $0.1 \mathrm{mmol} / 1$ to $8 \mathrm{mmol} / 1$. Initial experiments gave the approximate optimal substrate concentration at each temperature. They were then repeated using a range of concentrations around this value. Reduced $\beta$-nicotinamideadenine dinucleotide solutions were prepared to give reaction concentrations in the range $30 \mu \mathrm{mol} / 1$ to $240 \mu \mathrm{mol} / \mathrm{l}$. S $\phi$ rensen phosphate buffer, $67 \mathrm{mmol} / \mathrm{l}$, was prepared in the $\mathrm{pH}$ range $6.2-8.0$ at $20^{\circ} \mathrm{C}$. The tissue filtrate sample volume was $20 \mu 1$ and the reaction was initiated by adding $50 \mu$ l of substrate. Total reaction volume was $1.07 \mathrm{ml}$.

\section{Results}

Maximal assay conditions for lactate dehydrogenase with pyruvate as substrate were established at $25,30,35,37$, 40,45 and $50^{\circ} \mathrm{C}$ using the heart $\left(\mathrm{LDH}_{1}, \mathrm{LDH}_{2}\right)$ and liver $\left(\mathrm{LDH}_{4}, \mathrm{LDH}_{5}\right)$ preparations. The initial series of experiments at each temperature investigated the effects of changes in $\mathrm{pH}$ over a broad range of pyruvate concentrations. The results given in figure 1 illustrate the experimental work carried out in the whole series. Maximal lactate dehydrogenase activity of the heart tissue supernatant at $50^{\circ} \mathrm{C}$ was found with a $3 \mathrm{mmol} / 1$ pyruvate concentration at $\mathrm{pH} 6.8$.

The next group of experiments used the buffer and substrate concentrations which the earlier experiments had shown gave maximal activity at each temperature. The lactate dehydrogenase activity of both tissues at each temperature was then measured over a.wide range of NADH concentrations. The results obtained with liver tissue at $35^{\circ} \mathrm{C}$ using $3.2 \mathrm{mmol} / 1$ pyruvate and buffer pH 7.4 are shown in figure 2. Maximal activity was obtained with $120 \mu \mathrm{mol} / 1 \mathrm{NADH}$ in the reaction mixture.

Table 1 contains full details of the conditions found to give maximal activity at each temperature with each tissue. Using these conditions the lactate dehydrogenase activity of the filtrate of freshly homogenised human heart and liver tissue was measured. These measurements for each tissue over the stated range of temperatures were carried out over five hours. This short time interval ensured that no differences found were due to loss of enzyme activity with time, or to differences in the reagents. The velocities obtained using these maximal assay conditions are presented in table 2 . Using this data Arrhenius plots, i.e. log. initial velocity against inverse absolute temperature, were obtained from the lactate dehydrogenase activities of the heart and liver. tissues (fig. 3).

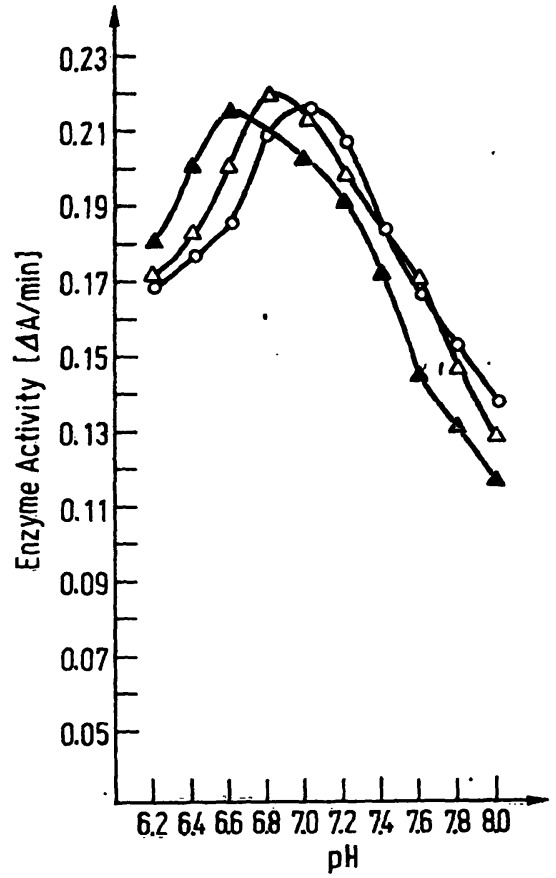

Fig. 1. Variation of enzyme activity at $50^{\circ} \mathrm{C}$ of heart tissue extract with buffer $\mathrm{pH}$ at different concentrations of pyruvate.

$\triangle \longrightarrow \quad 2 \mathrm{mmol} / 1$

$\triangle \longrightarrow \quad 3 \mathrm{mmol} / \mathrm{l}$

○— $4 \mathrm{mmol} / \mathrm{l}$

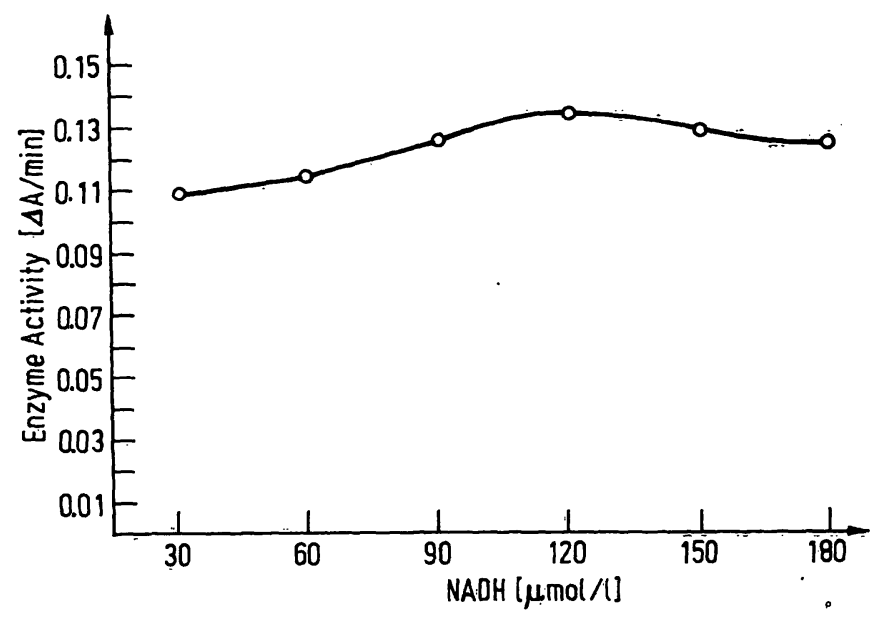

Fig. 2. Variation of enzyme activity at $35^{\circ} \mathrm{C}$ of liver tissue extract with NADH concentration at $3.2 \mathrm{mmol} / 1$ pyruvate and $\mathrm{pH} 7.4$.

Tab. 1. The pyruvate concentrations, NADH concentrations and buffer $\mathrm{pH}$ giving maximal activity with heart and liver tissue extracts at each of the stated temperatures.

\begin{tabular}{ccccccc}
\hline \multicolumn{3}{c}{ Pyruvate [mmol/1] } & \multicolumn{2}{c}{ Phosphate Buffer-pH } & \multicolumn{2}{c}{ NADH[ $\mu \mathrm{mol} / \mathrm{l}]$} \\
& Heart & Liver & Heart & Liver & Heart & Liver \\
\hline $25^{\circ} \mathrm{C}$ & 0.3 & 0.7 & 7.2 & 7.2 & 90 & 120 \\
$30^{\circ} \mathrm{C}$ & 0.4 & 1.7 & 7.2 & 7.4 & 120 & 120 \\
$35^{\circ} \mathrm{C}$ & 0.6 & 3.2 & 7.2 & 7.4 & 120 & 120 \\
$37^{\circ} \mathrm{C}$ & 1.0 & 3.7 & 7.2 & 7.4 & 120 & 120 \\
$40^{\circ} \mathrm{C}$ & 1.5 & 4.2 & 7.0 & 7.4 & 150 & 150 \\
$45^{\circ} \mathrm{C}$ & 2.3 & 5.1 & 7.0 & 7.4 & 150 & 150 \\
$50^{\circ} \mathrm{C}$ & 3.0 & 6.2 & 6.8 & 7.2 & 150 & 150 \\
\hline
\end{tabular}


Tab. 2. Lactate dehydrogenase activities of heart and liver tissue extracts using the maximal assay conditions at each of the stated temperatures.

\begin{tabular}{lcc}
\hline & \multicolumn{2}{c}{ Lactate dehydrogenase activity [U/1] } \\
Temperature & Liver tissue & Heart tissue \\
\hline $25^{\circ} \mathrm{C}$ & 617 & 388 \\
$30^{\circ} \mathrm{C}$ & 832 & 553 \\
$35^{\circ} \mathrm{C}$ & 1161 & 819 \\
$37^{\circ} \mathrm{C}$ & 1264 & 967 \\
$40^{\circ} \mathrm{C}$ & 1626 & 1204 \\
$45^{\circ} \mathrm{C}$ & 2200 & 1733 \\
$50^{\circ} \mathrm{C}$ & 2632 & 2308 \\
\hline
\end{tabular}

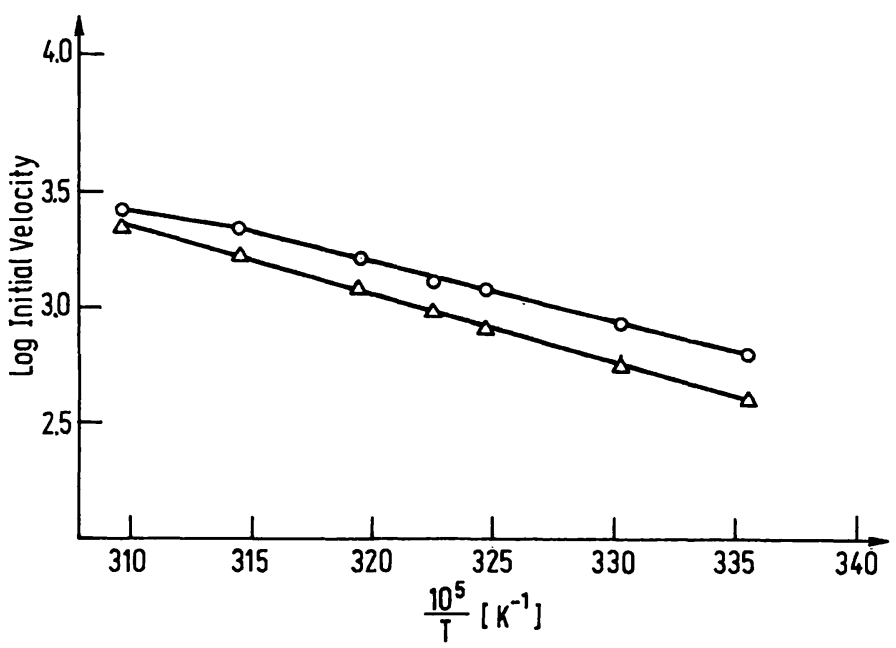

Fig. 3. Effect of temperature on the activity of the lactate dehydrogenase isoenzymes, plotted according to Arrhenius.

$\mathrm{LDH}_{4}$ and $\mathrm{LDH}_{5}$ (liver tissue) $\mathrm{0}-0$

$\mathrm{LDH}_{1}$ and $\mathrm{LDH}_{2}$ (heart tissue) $\Delta-\Delta$

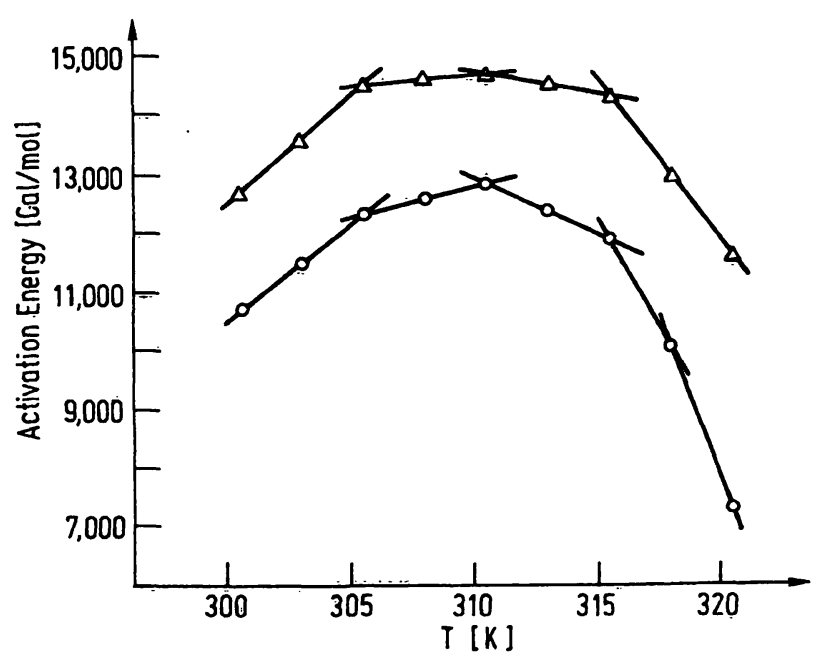

Fig. 4. Activation energies $(\mathrm{Cal} / \mathrm{mol})$ of the lactate dehydrogenase isoenzymes plotted against absolute temperature. $\mathrm{LDH}_{4}$ and $\mathrm{LDH}_{5}$ (liver tissue) $\bigcirc-0$ $\mathrm{LDH}_{1}$ and $\mathrm{LDH}_{2}$ (heart tissue) $\Delta-\Delta$

Activation energies $(\mathrm{Cal} / \mathrm{mol})$ were then calculated from the Arrhenius equation at $5^{\circ} \mathrm{C}$ intervals and were plotted against temperature (fig. 4).

\section{Discussion}

It has been claimed (1) that there is a significant deviation from linearity at $37^{\circ} \mathrm{C}$ for lactate dehydrogenase (LDH) activity of the fast and slow moving isoenzymes. However, the Arrhenius plots (figure 3) in this study are linear with both isoenzyme preparations up to $45^{\circ} \mathrm{C}$. There is a suggestion that the linear relationship is lost between $45^{\circ} \mathrm{C}$ and $50^{\circ} \mathrm{C}$, particularly with the liver tissue.

The activation energies found in this study were obtained from enzyme reaction velocities in their only meaningful situation, that is where the enzyme is saturated with substrate at each temperature. A similar pattern was exhibited by both the heart and liver tissue supernatants (fig. 4). This pattern was also obtained when the experiments where repeated. Interpretation of the significance of these results involves a large measure of speculation as they exhibit a number of surprising features. Both isoenzyme preparations show several points of inflexion, in each case occurring at the same temperatures. It can be safely stated from the results. that the $\mathrm{LDH}_{1}$ and $\mathrm{LDH}_{2}$ isoenzymes are more efficient, that is they have a greater turnover number, than $\mathrm{LDH}_{4}$ and $\mathrm{LDH}_{5}$. Each inflexion represents a change in reaction kinetics, possibly a conformational change in the enzyme. It is interesting that both peak at $37^{\circ} \mathrm{C}(310 \mathrm{~K})$ though no great significance can be read into this finding. Beyond $37^{\circ} \mathrm{C}$ less activation is obtained with rise in temperature.

One conclusion of this study which does not involve speculation is that no arguments produced in any controversy regarding the temperature at which enzyme activity may be measured, should be based on incomplete information. Arrhenius plots are not valid unless the enzyme is saturated with substrate. Conclusions should not, therefore, be drawn from them when a single concentration of substrate has been used over a range of temperatures.

\section{Acknowledgements}

The author gratefully acknowledges the assistance he has received from several sources:

The skill of Mr. J. Gilchrist, the LKB Scottish Engineer, who made the LKB 8600 Reaction Rate Analyser a variable temperature instrument.

The Scottish Home and Health Department (New Medical Developments) who provided the LKB 8620 Cooling Stage.

The time, patience, advice and criticism of Mr. John King, Principal Biochemist at Glasgow Royal Infirmary.

\section{References}

1. Szasz, G. (1974), this j. 12, 166-170.

2. Dixon, M. \& Webb, E. C. (1965), Enzymes; Longmans, Green \& Co. Ltd.

Dr. Matthew J. McQueen Director, Clinical Chemistry Camp Hill Hospital Halifax, Nova Scotia Canada 
